\author{
Miomir Korać \\ Arheološki institut Beograd \\ Radmila Pavlović \\ Rudarsko-geološki fakultet Beograd \\ Nemanja Mrdjić \\ Arheološki institut Beograd
}

904"652":528.8(497.11)

007:528.9]:004

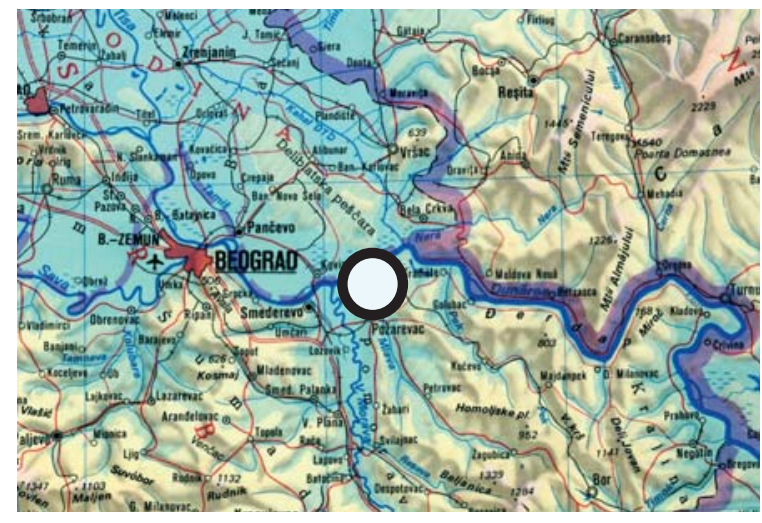

Viminacium, Stari Kostolac, Srbija LAT 44 44'09" / LONG 21 12 ' 42"

\title{
VIMINACIJUM - DALJINSKA DETEKCIJA I GIS
}

\begin{abstract}
ABSTRAKT
Savremena arheološka istraživanja postala su nezamisliva bez primene daljinske detekcije. Veliki arheološki projekti realizuju se mnogo brže, objektivnije i pouzdanije korišćenjem ove tehnologije. Mogućnosti primene daljinske detekcije su neograničene. Pored složenog proučavanja prirodnih uslova, vrši se prikupljanje arheoloških nalaza sa površine, traga se za oblicima prikrivenim u reljefu $i$ rekonstruišu se uzroci koji su doveli do zatrpavanja objekta. Izrađuju se precizni planovi raskrčenog $i$ raščišćenog terena. Stalni tehnološki razvoj, pogotovo kada su u pitanju računari korišćeni u procesu daljinske detekcije, otvara nove mogućnosti za njenu primenu u arheologiji.

Upraksi, rezultati dobijeni daljinskom detekcijom se kombinuju sa georadarskim imagnetometarskim istraživanjima. Najbolji primer ovakvog multidisciplinarnog istraživanja je lokalitet Viminacijum.

U Viminacijumu, rimskom gradu i vojnom logoru, daljinskom detekcijom je otkriveno preko 20 objekata što je veoma važno za buduća arheološka istraživanja. Najznačajniji otkriveni objekti su: akvedukt, carski mauzolej, amfiteatar, severna kapija vojnog logora (porta praetoria) i velike terme.

KlJuČne reči: dalJinska detekCiJa, ViminaCiJum, aerofotografiJa, SATelitski Snimci, GIS, GEographic Information System, AERosnimCi.
\end{abstract}

Početni uslov za rad na Projektu bila je primena daljinske detekcije. Prvi put je kod nas na jednom arheološkom lokalitetu izvršena stereoskopska analiza aerosnimaka u krupnoj razmeri' ${ }^{1}$.

1. Stereoskopsku analizu aerosnimaka područja Viminacijuma uradila je profesor Rudarsko-geološkog fakulteta na Katedri za daljinsku detekciju dr Radmila Pavlović. Kada smo uspostavljali medusobnu saradnju i pokrenuli zajednički rad na analizi aerosnimaka arheološkog lokaliteta Viminacijum, nisam ni pretpostavljao da ću, osim članka, dobiti i prijatelja. Najtoplije joj zahvaljujem na prijateljstvu. Korać, M. - Pavlović, R., 2004, Application of remote sensing in the Roman Town and Legionary
Savremena arheološka istraživanja danas su nezamisliva bez primene daljinske detekcije. Prva arheološka aeroprospekcija izvedena je 1913. godine, kada je iz balona izvršeno snimanje Ostije, luke iz rimskog perioda nadomak Rima. Tada je ser Henry Wellcome napravio prve aerosnimke ovog lokaliteta. U odnosu na te pionirske korake, danas postoje čitave institucije, kao što je Nacionalna biblioteka za aerosnimke u Engleskoj koja, počev od 1906. godine do današnjeg dana, čuva preko

Camp of Viminacium, MECEO, Beograd 2004. 
750.000 kosih aerosnimaka i preko 3.000 .000 vertikalnih aerosnimaka iz perioda od 1940. do 1979. godine. ${ }^{1}$ Pored kompleksnog izučavanja prirodnih uslova, ovom metodom se obavlja prepoznavanje arheoloških ostataka na površini terena, uočavaju odrazi pokrivenih objekata u reljefu, rekonstruišu događaji koji su doveli do pokrivanja i izrađuju precizni planovi otvorenih i očišćenih nalazišta. ${ }^{2}$ Rezultati dobijeni daljinskom detekcijom često se kombinuju sa georadarskim i magnetometrijskim istraživanjima, što je slučaj i $\mathrm{u}$ istraživanjima Viminacijuma.

Poznatoje da postoje dva tipa aerosnimaka: kosi i vertikalni snimci. Svaki od njih ima i prednosti i mane, ali oba, u preklopivim stereoskopskim parovima, mogu biti korišćena za dobijanje trodimenzinalnog modela. Primena računara u iščitavanju aerosnimaka dala je novu dimenziju ovoj oblasti. Aerosnimci u arheologiji su danas osnova za kompjutersku rektifikaciju, odnosno za finije detektovanje arheoloških objekata. ${ }^{3}$

Primenametodadaljinskedetekcijeuarheologiji, posebno na Viminacijumu, podrazumeva primenu različitih vrsta snimaka za prikupljanje podataka o arheološkim objektima ili za izradu preciznih osnova već istraženih nalazišta. Zavisno od senzora kojim se teren snima, u upotrebi mogu biti različite vrste snimaka. U standardnoj upotrebi su crno-beli, kolor i infracrveni kolor snimci koji se, po pravilu, daju u stereotehnici. Multispektralni skenerski snimci, infracrveni skenerski i radarski snimci dobijaju sve značajnije mesto u arheološkim istraživanjima. Izbor vrste snimka, kao izvora podataka, zavisi od namene, potrebe, zahteva istraživanja i, naravno, materijalnih mogućnosti. ${ }^{4}$

Bitno svojstvo snimaka je mogućnost sagledavanja celine. Značaj sagledavanja celine jeste prikupljanje kvalitativno i kvantitativno novih podataka o terenu. Nov kvalitet omogućava analiza podataka nevidljivih delova

1. Bradford, 1957

2. Renfrew, Bahn, 2000

3. Gumerman, Lyons, 1971

4. Schaber, Gumerman, 1989 spektra elektromagnetne energije. To pružaju multispektralna skenerska, infracrvena termalna i radarska snimanja. Na tim snimcima mogu se utvrditi i pojedina svojstva terena, nedostupna neposrednom terenskom osmatranju, posebno delova terena pokrivenih metarski do dekametarski debelim naslagama naknadno donetog materijala.

Prevođenjem snimka u digitalnu formu, ili njegovom izradom u takvom formatu, otvaraju se nove mogućnosti daljinske detekcije. Tako pohranjen snimak se lako i brzo prevodi u ortogonalnu projekciju, što obezbeđuje izvanredno preciznu topografsku podlogu za lociranje podataka, sa tačnošću instrumentalnog kartiranja. Osim toga, digitalna forma snimaka omogućava njihovo procesiranje, primenom odgovarajućih programa. ${ }^{5}$ Procesiranje snimaka, kao postupak prikupljanja informacija, postao je standardan postupak kod višekanalnih multispektralnih snimaka.

Iako korišćenje snimaka u arheološkim istraživanjima traje skoro čitav vek, iskustva u našoj zemlji su izuzetno skromna. Sa žaljenjem se može reći da ne postoji arheološki lokalitet za koji je urađena stereoskopska analiza aerosnimaka u krupnoj razmeri, analiza infracrvenih, termalnih ili radarskih snimaka. Ni za jedan lokalitet do sada nije urađeno procesiranje satelitskih snimaka visoke rezolucije u krupnoj razmeri.

Otkrivanje odraza arheoloških objekata u reljefu terena, danas pokrivenih naslagama različitog materijala, uspešno se obavlja stereoskopskom analizom aerosnimaka. Snimci načinjeni pri niskom položaju Sunca, rano izjutra ili kasno popodne, istaći će senke starih kanala ili odlagališta materijala, iskopanog pri izgradnji nekadašnjih objekata. Razlike u rastresitosti tla se manifestuju i promenom vlažnosti, koja se lako identifikuje na snimcima. Ove razlike otkrivaju stare arheološke strukture i tragove ljudske aktivnosti na tlu nekadašnjeg reljefa. Odrazi u reljefu i fine izmene tla su inače, pri neposrednim terenskim opažanjima, praktično nevidljivi fenomeni.

5. Limp, 1989 
Savremeni vegetacioni pokrivač verno odražava izmene tla. Promene u gustini, visini i boji vegetacije, kako stihijske, tako i one koje kontroliše čovek, mogu ukazati na postojanje različitih struktura, kao što su rovovi, zatrpani ostaci zidova, kanali i sl. Ovakvi fenomeni ponavljaće se iz godine u godinu, čak i kada arheološki ostaci leže znatno dublje od savremenog pedološkog sloja. Stoga je posebno korisna analiza snimaka klasičnih aero-stereo fotografija, infracrvenih ili radarskih snimaka, načinjenih u različitim periodima. ${ }^{6}$

Bitnu karakteristiku odraza arheoloških objekata, bilo u tonu ili u boji tla, bilo u vegetaciji ili u reljefu, čini oblik. Arheološke strukture su redovno pravilnih geometrijskih oblika. Geometrijski oblik potvrdiće tonske razlike tla, razlike u vegetaciji, kao i razlike u mikroreljefu terena. Oblici reljefa, nastali kao rezultat rada egzogenih geomorfoloških procesa, nikada ne pokazuju ovakve pravilnosti.

U cilju kvalitetne prospekcije, urađena je detaljna stereoskopska analiza aerosnimaka. Analizirani su aerosnimci dve generacije, u tri različite razmere. Stariji snimci načinjeni su 1979. godine u razmeri 1:7.500. Analiza je obavljena na fotogramima. Druga generacija snimaka, iz 1996. godine, urađena je u razmeri 1:26. 000, a analiza je izvršena na kontakt kopijama i njihovim uvećanjima u razmeri 1:10.000. Obe generacije su crno-beli panhromatski snimci. Arheološki podaci su prikupljani primenom standardnih kriterijuma. Rezultati analize obeju generacija i sve tri razmere snimaka iscrtani su na posebnim oleatama, položenim preko snimaka.

Prilikom analize snimaka koji su načinjeni 1979. i 1996. godine, uočavaju se određene sličnosti, ali i razlike. Razlike se ogledaju u tome da snimci iz 1979. godine pripadaju periodu pre komasacije parcela, koja je na ovom području spovedena 1981. godine. Naravno, na razlike utiču i uslovi snimanja, kao što su doba dana i godine, sušnost vegetacije, kulture zasejane na tom

6. Schaber, Gumerman, 1989 području u datom trenutku. Na snimcima iz 1979. godine, pod uticajem nekog od ovih faktora, vide se objekti koji ne postoje na snimcima iz 1996. godine. Na primer, vidljivi su objekti koji se nalaze ispred bedema rimskog grada Viminacijuma. Oni, po svoj prilici, predstavljaju kružne kule predgrađa Viminacijuma, što je za arheologe veoma važno otkriće (objekat 1, sl. 5-6).

Kakva nam nova saznanja, značajna za arheološka istraživanja, daje uporedna analiza ovih snimaka? Analiza aerosnimaka Viminacijuma pokazala je izuzetan broj nalaza, od kojih su neki, arheološkim iskopavanjima i potvrđeni. Pojedini od njih su potvrđeni geofizičkim metodama primenom geoelektrike i georadara.

Neposredno uz staro korito Mlave, nalazi se arheološki objekat koji upućuje na postojanje antičke luke. Detektovan je zid, verovatno deo nekadašnje klauzure (clausurae) koja je spajala samu luku sa gradom. Dužina zida je oko 70 metara i pretpostavlja se da je iznosila još toliko (objekat 2, sl. 5-6).

Gabarit rimskog grada i vojnog logora Viminacijuma je približno utvrđen. Dimenzije najužeg urbanog dela su oko $1,5 \mathrm{~km}$ x $0,85 \mathrm{~km}$, odnosno, nešto preko 125 hektara. Međutim, teritorija grada Viminacijuma, sa nekropolama i predgrađima, zauzimala je znatno veći prostor i iznosila je oko 450 hektara. Pažljivom analizom aerosnimaka, potvrđeni su bedemi rimskog grada. Rezultati ove analize potvrđeni su i georadarskim snimcima (objekat 3, sl. 5-6). Debljina severnog bedema tačno je utvrđena georadarskim merenjima.

Pod pravim uglom u odnosu na južni bedem grada, poređan je niz kružnih objekata, čija funkcija nije utvrđena. Moguće je da su u pitanju hramovi ili objekti vezani za carsku palatu, koja je svakako postojala na teritoriji grada Viminacijuma. Ova pretpostavka počiva na činjenici da nije bilo značajnijeg rimskog imperatora koji nije posetio Viminacijum, a neki su u njemu i duže boravili, ili ga posećivali u više navrata (objekat 4, sl. 5-6). Objekat, detektovan severno od kružnih objekata, 
bi mogao da bude hram (objekat 5, sl. 5-6). Istočno od pretpostavljenog hrama, nalazi se objekat koji ukazuje na postojanje gradske komunikacije (objekat 6, sl. 5-6). Ova komunikacija se nastavlja na gradsko kupatilo (thermae) (objekat 7, sl. 56). Severoistočno od gradskih termi nalazi se amfiteatar (amphitheatrum). Amfiteatar je približno kružne osnove, veličine oko 100 metara. Interesantno je da amfiteatar koristi severni gradski bedem kao jednu od svojih strana (objekat 8 - sl. 1, 5, 6).

Vojni logor (castrum), u kome je bila smeštena rimska legija VII Claudia pia fidelis, je jedan od objekata detektovanih primenom, kombinovanjem i analizom aerosnimaka, metodom geoelektrike, kao i georadarom (objekat 9, sl. 56). Utvrđeno je da su dimenzije vojnog logora 430 x 337 metara, odnosno površine oko 16 hektara. U centralnom prostoru vojnog logora jasno se izdvaja objekat kvadratne osnove. Reč je, o mestu gde je bio smešten glavnokomandujući vojnog logora (praetorium) (objekat 10, sl. 5-6). Detektovana je i istočna kapija vojnog logora (objekat 11, sl. 5-6).

Analiza aerosnimaka ukazala je na jednu izuzetnu mogućnost za sagledavanje istorijske slike Viminacijuma, koja je izazivala nedoumice proučavalaca. Naime, ne isključuje se mogućnost da je logor (castrum), u vreme nastanka u I veku, bio dvostruko veći, odnosno da je imao dimenzije oko 1000 x 430 metara, ili oko 43 hektara, i da u njemu nije bila smeštena samo jedna, već dve legije: IIII Flavia felix i VII Claudia pia fidelis ${ }^{1}$.

1. Pitanje prvobitnog logora legije IV Flavia felix, pre nego što je stacionirana u Singidunumu, ostalo je do danas nerazjašnjeno. Kao jedno od mesta na kome je mogla da bude stacionirana do 86. godine, pominje se i Viminacijum. Ovu tezu su zastupali Riterling i R. Sajm. Smatrali su da se legija IV Flavia felix ovde mogla nalaziti bar u vreme Domicijanovog Dačkog rata. Glavna smetnja za smeštaj dve legije na ovom prostoru bila je veličina logora u Viminacijumu. Uobičajene pretpostavke o veličini logora u Viminacijumu oslanjaju se na podatke koje su nam ostavili Mihajlo Valtrović i Miloje Vasić. Prvi je smatrao da su dimenzije logora u Viminacijumu 430 × 350 $\mathrm{m}$, a drugi - 442,7 x 385,6 m. Ove podatke su dalje preuzeli drugi istaživači (M. Mirković, V. Popović, i drugi). Poznato je da su legijski logori u kojima su bile smeštene
$\mathrm{Na}$ tu pretpostavku upućuju neke interesantne činjenice: južni bedem vojnog logora nadovezuje se na južni bedem grada Viminacijuma. $\mathrm{Na}$ snimcima se jasno vidi da su bedemi postavljeni u kontinuitetu, što je veoma indikativno, ako se ima u vidu činjenica da severni bedem grada i gradska struktura u tom delu negira (naravno ukoliko je postojao na tom mestu) severni bedem kastruma. Osnovno pitanje glasi - kako to da se južni bedem grada tako jasno detektuje i pokazuje kontinuitet u odnosu na južni bedem kastruma. Odgovor koji se nameće jeste da je imao neku funkciju. Pažljivom analizom aerosnimaka je uočeno da se na tom mestu nalazi objekat koji je postavljen neposredno uz južni gradski bedem. Objekat je pravougaone osnove sa zaobljenim stranama. Pretpostavka je da se na tom mestu, još od ranog perioda formiranja grada, najverovatnije već od druge polovine I veka, nalazio hipodrom (objekat 12, sl. 5-6). Naime, ukoliko je tačno da su u logoru bile smeštene dve pomenute legije, one su mogle da budu zajedno samo do Domicijanovog edikta iz 86. godine, kojim se zabranjuje stacioniranje dve legije u jednom logoru. Posle 86. godine u logoru je ostala samo legija VII Claudia pia fidelis i više nije bilo potrebe za tako velikim prostorom, pa je logor (castrum) skraćivanjem dobio dimenzije od 430 x 377 metara. Deo južnog bedema logora iskorišćen je kao jedna od strana novonastalog hipodroma.

U vezi sa tim mogu da budu i kružni objekti, postavljeni upravnou odnosu najužni bedem grada, koji nagoveštavaju postojanje komunikacije, ali i mogućnost postojanja carske palate, naročito imajući u vidu značaj koji je Viminacijum imao za Rimsko carstvo.

$\mathrm{U}$ pravcu istoka, u produžetku istočne kapije vojnog logora (registrovana je i georadarskim merenjima), detektovano je više objekata, grupisanih u dve celine. Prva, u vezi sa komunikacijama koje su vodile do susednog

dve legije imali znatno veće dimenzije, kao na primer u logor u Novesiumu koji je bio dimenzija 680 x 700 metara odnosno preko 40 ha. 

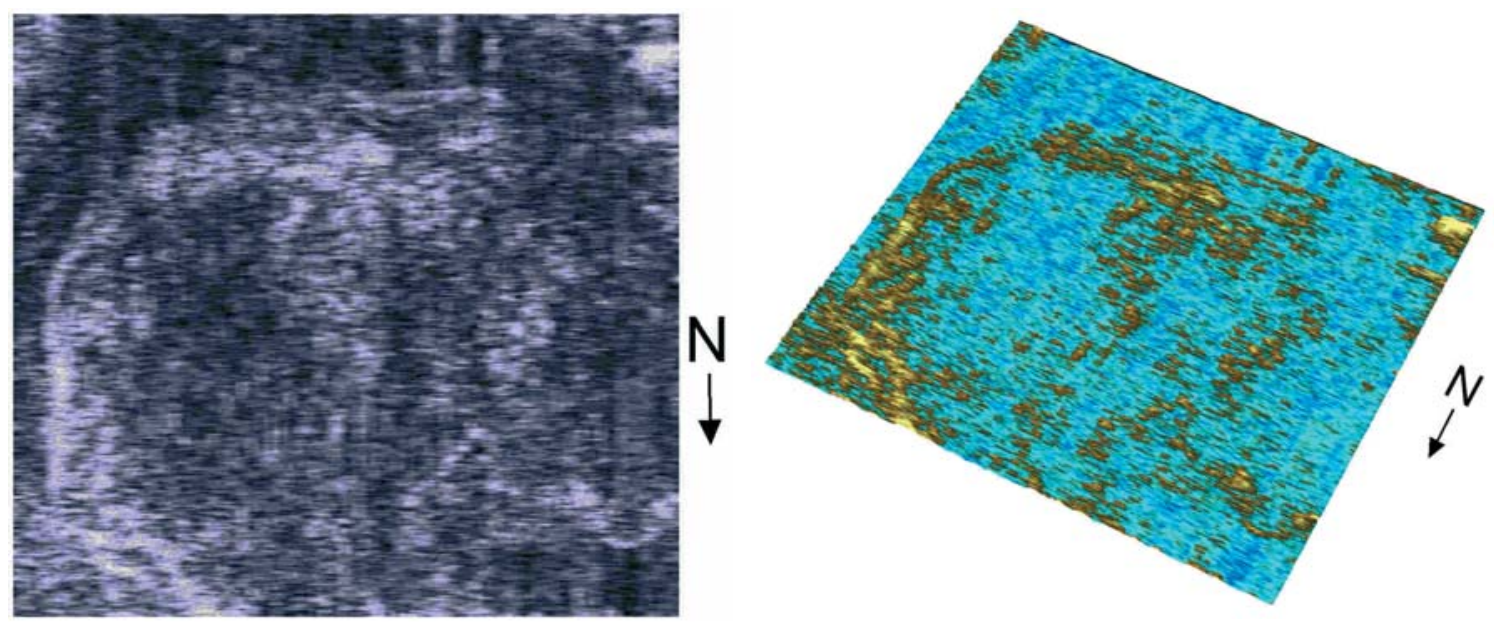

Slika 1. Amfiteatar. Georadarski snimci - horizontalni presek na dubini od 1,0 m (desno) i 3D prikaz (levo) Figure 1. Amphitheater. GPR survey results - Horizontal slice at depth of $1 \mathrm{~m}$ (right) and 3D model (left)
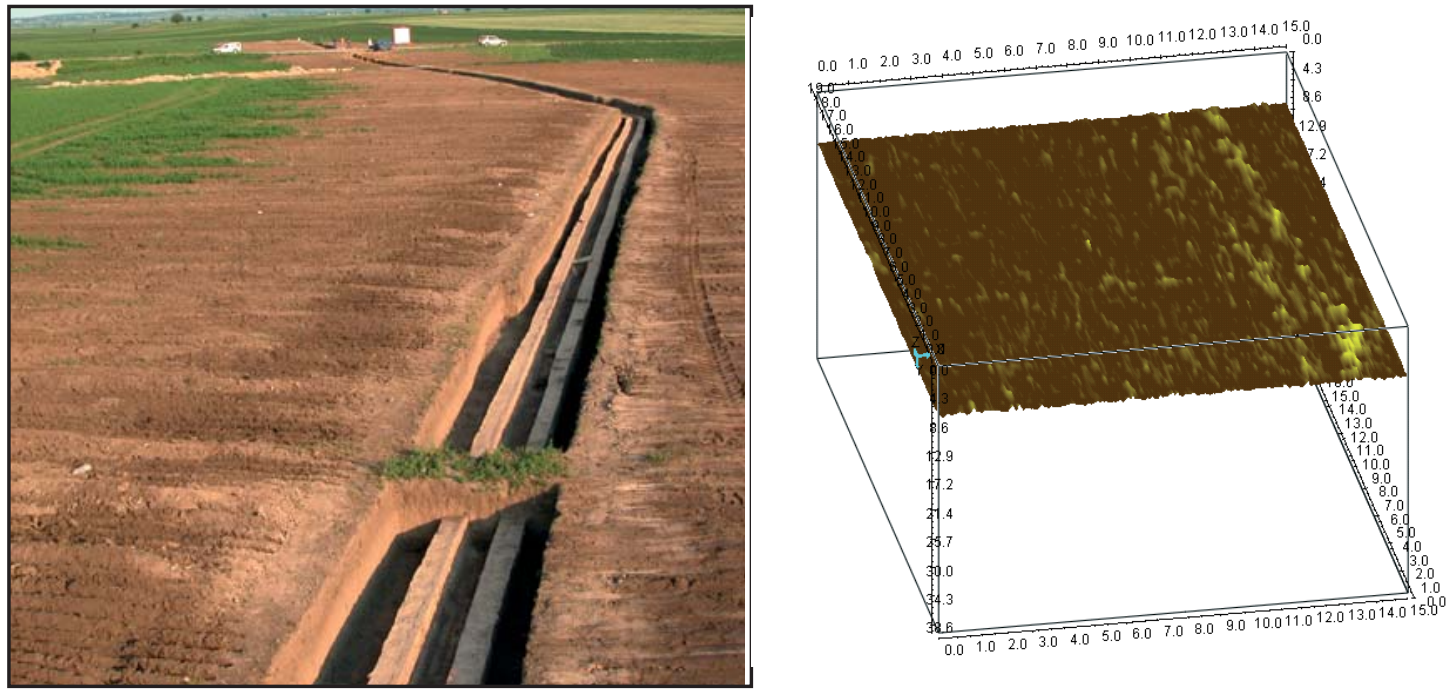

Slika 2. Rimski akvedukt. Iskopani gravitacioni kanali (desno) i georadarski snimak (levo)

Figure 1. Roman Aqueduct. Excavated channel (right) and GPR survey image (left)
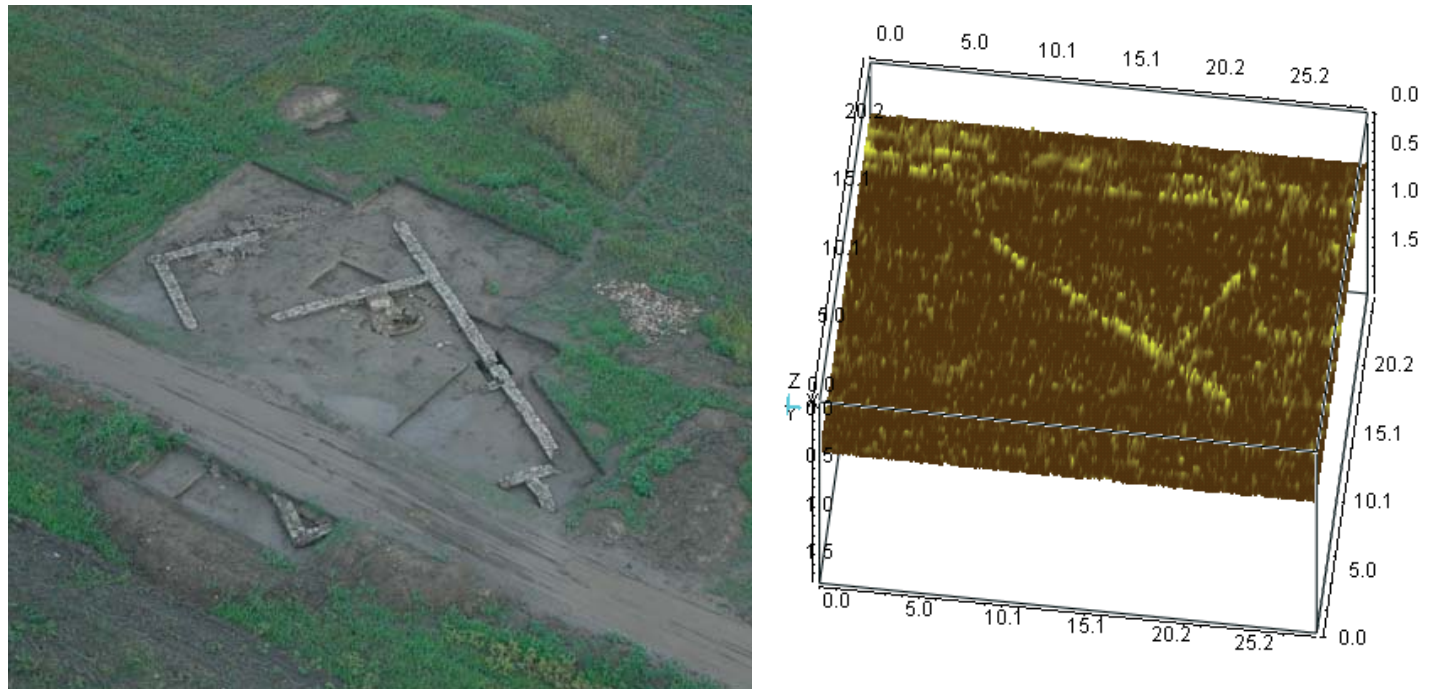

Slika 3. Rimska vila u Stigu. Situacija prilikom iskopavanja (desno) i georadarski snimak (levo) Figure 2. Roman villa at Stig. Aerial photo during excavation and GPR survey image (left) 
vojnog logora Lederate (objekat 13, sl. 5-6), i druga, koja se odnosi na vodosnabdevanje grada i vojnog logora (objekti 14, 15, 16, 17 na sl. 5-6). Georadarski snimak i fotografija sa arheoloških iskopavanja prikazane su na slici 2.

Objekat obeležen brojem 18 ima formu tumula, ali njegova funkcija nije do kraja jasna (sl. 56). Definisanje objekata pod brojem 19, 20 i 21 takođe zahteva arheološka iskopavanja i naknadnu interpretaciju (sl. 5-6).

Treba pomenuti i objekat koji je otkriven georadarom, a kasnije arheološki istražen. Radi se o kasnoantičkoj građevini sa apsidom iz perioda IV veka (sl. 5-6). Georadarski snimak i fotografija sa arheoloških iskopavanja prikazane su na slici 3.

Primenom daljinske detekcije na istraživanje rimskog grada i vojnog logora Viminacijuma, registrovano je preko 20 izuzetno važnih, krupnih objekata kao što su: akvadukt, mauzolej, amfiteatar, severna kapija vojnog logora (Porta praetoria) i terme.

Stereoskopska analiza lokaliteta biće upotpunjena u narednom periodu i infracrvenim snimcima. Nesumnjivo je da će prečišćeni satelitski snimci dati dragocene informacije o ovom izuzetnom lokalitetu.

\section{ANALIZA DIGITALNIH SNIMAKA I GIS}

Računari su uneli pravu revoluciju u primeni daljinske detekcije. Digitalni snimci su mnogo manipulativniji od stereoparova ili negativa. Softver za obradu digitalnih slika omogućio je korekcijedigitalnogsnimkauciljuisticanjatraženih objekata. To je moguće izvesti pojačavanjem ili umanjivanjem osvetljenja, kontrasta i boja, kao i nizom drugih efekata vezanih za grafičku obradu.

$\mathrm{Na}$ priloženim oleatama prikazan je rezultat daljinske detekcije na nivou grada $\mathrm{i}$ makrostruktura. S druge strane, daljinska detekcija se primenjuje i za lociranje manjih pojedinačnih objekata ili prigradskih kompleksa. Na slici 7 prikazan je jedan od objekata koji je detektovan pojačavanjem kontrasta na aerosnimcima. Radi se o objektu koji je u neposrednoj blizini grada i koji se vidi na samo jednom iz čitave serije snimaka. Prikazani su originalni segment, snimak sa pojačanim kontrastima i jedna od mogućih interpretacija otkrivenog objekta.

Svi raspoloživi aerosnimci Viminacijuma digitalizovani su u visokim rezolucijama. Digitalizovane su i vektorisane topografske karte. Na taj način stvorena je široka osnova za primenu kontinuirane daljinske detekcije u okviru GIS-a (Geographic Information System). Formirana je kompleksna baza podataka. Mesta prepoznatljiva na aerosnimcima snimljena su na terenu pomoću sistema za globalno pozicioniranje (Global Positioning System - GPS). Time je omogućeno georeferenciranje aerosnimaka i na taj način su pozicionirani u globalnom kooordinatnom sistemu. ${ }^{1}$ Svaka tačka na snimku dvodimenzionalno je definisana u prostoru. ${ }^{2}$

Otkrivene objekte, koji su uočeni na aerosnimcima, moguće je sa visokom preciznošću locirati na terenu. Proces je jednostavan: koordinate se iz GIS baze prenesu u registrator Trimble 5800 GPS uređaja. GPS zatim putem satelitske navigacije dovodi istraživača do same lokacije.

Velike promene u izgledu terena čine ponekad vizuelnu orijentaciju veoma teškom. Ovo dolazi do izražaja pogotovo kada su u pitanju aerosnimci stari više decenija. U tim slučajevima je primena GIS-a i GPS-a nezamenljiva. Komasacija iz 1981. godine i gradnja termoelektrane, na prostoru Viminacijuma, uneli su drastične promene na mikroregionalnom nivou. Komasacijom je promenjena orijentacija njiva ${ }^{3}$. Stari putevi su

1. Georeferenciranje je izvršeno na osnovu tačaka koje su lako vidljive i precizno određene na aerosnimcima. Kao lokacije za georeferenciranje izabrane su raskrsnice, mostovi i jasno vidljive zgrade. Za geodetsko snimanje tačaka korišćen je GPS totalna stanica visoke subsantimetarske preciznosti - Trimble 5800.

2. Trodimenzionalno definisanje tačaka je moguće na osnovu digitalnog modela terena čija se izrada za prostor Viminacijuma vrši u ovom trenutku.

3. Njive su na snimcima iz 1996. godine orijentisane $u$ pravcu sever - jug. Na snimcima iz 1979. godine one su orijentisane istok - zapad. 
nestali, a trasirani su novi. Prilikom gradnje termoelektrane skrenut je tok reke Mlave staro korito koje se vijugalo ka severoistoku je presečeno, a novo vodi ka severozapadu. Usled svih tih promena, objekte koji se uočavaju na snimcima iz vremena pre 1979. godine, vizuelno je veoma teško locirati na terenu. Većina nekadašnjih orijentira je usled savremenih zemljanih radova nestala ili je uništena. Georeferenciranje je vršeno na retkim mestima koja su ostala nepromenjena na svim aerosnimcima. Sada je satelitskom navigacijom jednostavno naći traženu tačku i po izmenjenoj situaciji na terenu.

GIS dozvoljava kombinaciju i uporednu analizu više aerosnimaka, karata ili skica po nivoima (layers). Dodavanjem različitih procenata transparencije gornjim nivoima mogu se porediti detalji na više snimaka istovremeno. Ovim procesom moguće je tražiti detalje koji su bili vidljivi samo pojedinih godina ili preciznije definisati one koji su vidljivi na svim snimcima.

Georeferenciranje starih skica i planova dalo je izanredne rezultate. Naime, moguće ih je povezati sa aerosnimcima i geofizičkim snimcima u GIS bazi čime se dobija detaljna slika o stanju antičkih ostataka bez dugotrajnih iskopavanja.

Primena daljinske detekcije nesumnjivo ima perspektivu u arheologiji. Viminacijum je primer kako se uz dobru metodologiju mogu postići odlični rezultati. U strateškom pogledu ona bi praktično trebalo da bude početak svakog ozbiljnije definisanog projekta i osnova za sistematska istraživanja.

\section{BIBLIOGRAFIJA}

\section{Bradford 1957}

Bradford, I. S. P., 1957: Ancient Landscapes: Studies in Field Archaeology, London.

\section{Daniel 1981}

Daniel, G. E., (ed.) 1981: Towards a History of Archaeology, London.

\section{Gumerman, Neely 1972}

Gumerman G. J. \& Neely, 1972: An archaeological survey of the Tehuacan Valley, Mexico:A test of color infrared photography, American Antiquity 37, 520-527.

\section{Gumerman, Lyons 1971}

Gumerman, G. J. and T. R. Lyons, 1971. Archeological Methodology and Remote Sensing. Science 172:126-32.

\section{Limp 1989.}

Limp, W. F. 1989. The Use of Multispectral Digital Imagery in Archeological Investigations. Fayetteville: Arkansas Archeological Survey.

\section{Pritchard 1987}

Pritchard, J. B., (ed), 1987: The Times Atlas of the Bible, London.

\section{Renfrew, Bahn 2000}

Renfrew, C - Bahn, P. 2000: Archaeology, Theories Methods and Practice, 3rd ed., London 2000, 71-116.

\section{Schaber, Gumerman 1989}

Schaber, G. G., and G. J. Gumerman, 1989. Infrafed Scanning Imagery: An Archeological Application. Science 164: 712-13.

\section{Wilson 1975}

Wilson, D. R., 1975: Aerial Reconnaissance for Archaeology. Concil for British Arch. Res. Rep., 12, London.

\section{Wilson 1982}

Wilson, D. R., 1982: Air Photo Interpretation for Archaeologists, Batsford, London. 


\section{VIMINACIUM - REMOTE SENSING AND GIS}

$* * *$

\section{INTRODUCTION}

Archaeological sites may be discovered in various ways. Some of the famous sites were visible by naked eye, like Egyptian pyramids, Tehuacan pyramids (in the vicinity of present Mexico City), the Chinese Wall, or Forum in Rome [1]. However, some extraordinary sites, like the Lasko cave, or sites in China with a clay soldiers army made for the first Chinese Emperor, have been discovered by accident. Naturally, in order to discover archaeological sites, systematic archaeological researches with precisely defined goal are necessary as well.

A method by which certain sites are identified is primarily based on surveys executed according to the surface artefacts sensing. Such surveys include, first of all, consulting of literary sources (Schliman's consulting of Homer's works), documentary material, as well as a whole series of geo-physical methods, especially aerial reconnaissance. Usually, more methods are combined, and often all of them [2], [3], [4], [5].

The first archaeological aerial survey was carried out in 1913, when aero-photos of Ostia, a Roman period port near Rome, were taken from the demijohn, by Sir Henry Wellcome [6], [7]. Those were the pioneer steps in the field, while nowadays there are big institutions using this method, like National Library of aero-photos in England, housing over 750.000 oblique aerophotos, taken from 1906 up to this day, and over 3.000.000 vertical aero-photos from the period from 1940 to 1979.

There are two types of aero-photos: oblique and vertical ones. Each of them has advantages and shortcomings, but what matters is that both types in overlapping stereoscopic pairs may be used in order to get a three-dimensional model. Computers used to read aero-photos have given the new dimension to this field. Aero-photos in archaeology today are basis for computer rectification, i.e.fine detection of archaeological artefacts.
Significant element in archaeological research is the choice of a site-a potential deposit. Most sites are still discovered by chance. Most often, no visible traces are saved on the surface layers, so sites are usually discovered during major construction works, building of trafficcommunications, dams, surface excavations, urbanization of large areas, and so on.

Choice of a research site may be based on the study of conditions which may have led to the formation of settlements in the past, military camps, etc. Such conditions include certain land reliefs, opportunity for regular watersupply, hunting and fishing, plant growing, favourable climatic conditions, existence of land and water ways of transport of people and goods.

Conditions may be studied through field surveys, analyses of topographic material, and archive data. However, such study is much more faster, objective and reliable when using remote sensing method [8].

Remote sensing offers great opportunities. Besides the complex study of natural environmental conditions, survey of archaeological artefacts in the surface layer is carried our, shapes covered in relief are identified, and events which have caused the covering reconstructed. Also, precise plans of the open and cleaned sites are designed. Constant technological development opens new options for its application in archaeology.

\section{REMOTE SENSING IN ACRHAEOLOGY}

Remote sensing in acrhaeology means the use of various images for collecting data on archaeological artefacts, or for making precise maps of already researched sites. Depending on a sensor presenting a site, different types of images are used. Usually, black-white, colour and infrared color photos are used, in stereotechnique. Multispectral csanning imagery, infrafed scanning imagery and radar images 
keep getting important place in archaeological researches. Choice of image type as a data source depends on its purpose, research demands, and, of course, financial means.

Important characteristic of photos is possibility of viewing the whole picture, which means collection of qualitatively and quantitatively new data on the field. The new quality is based on the analysis of data on the invisible parts of spectrum of electromagnetic energy. Multispectral scanning, infrared, thermal and radar images enable it. Such images also enable identification of certain site characteristics which may not be discovered by direct field research, especially those strata covered with a few or dozen meters deep layers of later, added materials.

New options for remote sensing open when images are turned into a digital form, or acquired in such format. Such saved image is easily and quickly changed into orthogonal projection, offering meticulously precise topographic base for data location, detailed instrumental mapping. Besides, digital format of images enables their processing, by using adequate software [9]. Image processing, as a procedure for data collection from them, has become a standard procedute with multi-channel multispectral images.

Imagery is being used in archaeological researches almost for a century. In our country, such experiences are rare. We may regretfully notice that there is no archaeological site where stereoscopic analysis of aero-photo in a large scale has been done, nor analysis of infrared, thermal or radar images. High resolution satelite shots (and in large scale) processing has not been done for any site up to now.

Shapes of archaeological artefacts are successfully detected in land reliefs, today covered with layers of various materials, by aero-photos stereoscopic analysis. Photos taken during the Sun low position, early in the morning or late in the afternoon, highlight shadows of old channels, or deposits of material excavated during the construction of past buildings. Various soil density manifests itself through changed humidity, easily identified on photos. Such varieties show previos archaeological structures, and traces of human activities in the area of past reliefs. reflections in relief and fine soil changes are practically invisible phenomena during the direct field study.
Present vegetation reflects exact soil changes. Changed vegetation density, height and colour, elemental or man-controlled, may point out to the existence of various structures, like ditches, covered remains of walls, channels, etc. Such phenomena shall keep repeating year after year, even when archaeological artefacts are located much deeper than the present pedological stratum. That is why the analysis of standard aero-stereophotos, infrared or radar images taken in various periods is especially useful [10].

Shape is a significant feature of archaeological artefacts reflection, either in soil tone or colour, in vegetation or relief. Archaeological structures are always of regular, symmetrical geometrical shapes. Geometrical shape confirms tone soil varieties, differences in vegetation, as well as different micro-relief. Relief shapes which are consequences of the activities of exogenous geomorphological processses never show such regularities.

Application of remote sensing in the classical town and military camp of Viminacium

Viminacium lis located in the vicinity of villages Stari Kostolac and Drmno, $95 \mathrm{~km}$ away from Belgrade, near the Mlava River mouth into the Danube. In the area covering many hectares, a classical town is located, together with a military camp, with all the structures a developed town of that period included. It is one of the 40 large camps on the Roman Empire territory. It is extremely significant, having in mind a fact that, apart from Carnuntum, Petronel near Vienna, it was a single legion camp located in an open area, not endangered by later settlements. In light of the fact that archaeological researches of Carnuntum were done at the turn of the 20th century, using then available scientific methods, application of the new technologies in the Viminacium research has special significance.

In order to do qualitative survey of the Viminacium site, detailed stereoscopic analysis of aero-photos was carried out. Two generations of aero-photos were analysed, in three different scales. Older photos were taken in 1979, in the 1:7.500 scale. The analysis was done on photograms. Another generation of snapshots from 1996 in the 1:26.000 scale was analysed on contact copies and their magnified copies in the 1:10.000 scale. Both generations were black- 
white panchromatic photos. Archaeological data were collected using standard criteria. Analyses results of both generations and all the three scales of snapshots were drawn by special oleate, laid over the photos.

During the analysis of shots taken in 1979 and 1996, certain similarities were noticed among them, as well as differences. They are different in a sense that photos taken during 1979 belong to the period before the redistribution of lots, carried out in this region in 1981. Other factors influencing the diffirences which should be taken into account are photographing conditions, like time of the day or year, dry vegetation at the moment, as well as vegetation types cultivated in the region at the moment of photographing. Any of the mentioned factors has influenced the process in such a way that on 1979 photos structures are visible which on photos from 1996 are not. For example, structures in front of the Viminacium classical town rampart are visible. They are, most likely, round towers of a town suburb. For archaeologist, it is an important discovery (Structure 1, Fig. 5-6).

What may we archaeologist learn from the comparative analysis of these photos? Analyses of the Viminaciuma aero-photos has shown extreme number of finds, some of which have been confirmed by archaeological excavations. Some of them are also confirmed by geo-physical methods, using geoelectric instruments and georadar.

Immediately next to the old riverbed of the Mlava River there is a structure indicating a classical port. A wall was detected, most probably a clausurae connecting the port with the town. The wall of approximately 70 meters was previously, most probably, double long (Structure 2, Fig. 5-6).

General dimensions of the classical town and military camp have been determined. The narrowest urban zone of the town was app. $1,5 \mathrm{~km}$ x $0,85 \mathrm{~km}$ wide, covering over $125 \mathrm{ha}$. However, the territory of the town of Viminacium, together with necropoles and suburbs, has covered much larger area of app. 450 ha. Careful analysis of aerophotos has confirmed the ramparts of the classical town. Results of the analysis were confirmed by georadar shots (Structure 3, Fig. 5-6). Diameter of the Nothern rampart was precisely determined by georadar (georadar photo of the town Northern rampart).
Vertical to the town Southern rampart there are round structures, the function of which may be only guessed at the moment. They may be temples or structures connected with the imperial palace, which certainly existed on the territory of the Viminacium town. We say so in the light of the fact that there was no significant Roman emperor who has not visited Viminacium, while some of them stayed there for a longer period, or visited it a few times (Structure 4, Fig. 5-6). Structure detected north of them could also be a temple. (Structure 5, Fig. 5-6). East of the supposed temple, there is a structure indicating a town traffic structure (Structure 6, Fig. 5-6). This structure continues to the town bath (thermae) (Structure 7, Fig. 5-6). Northeast of the termae there is an amphitheater (amphitheatrum). Dimensions of the amphitheater of round basis are app. 100 meters. It is interesting and indicative for the overview of the town structures that the amphitheater uses the town northern rampart as one of its sides (Structure 8 on oleata, and georadar photo).

Military camp (castrum) where a Roman legion VII Claudia pia fidelis was placed is one of the structures detected by applying, combining and analysing aerophotos, geoelectric instruments and georadar (Structure 9, Fig. 5-6). Determined dimensions of the military camp are $430 \times 337$ meters, its approximate area 16 ha. In the central zone of the military camp there is a clear structure of square basis. It was surely camp headquarters (praetorium) (Structure 10, Fig 5-6). The camp eastern gate was also detected (Structure 11, Fig 5-6).

Analysis of the aerophotos of Viminacium has opened an exceptional option to perceive historical view of it. Namely, it is possible that the camp (castrum) during its creation, in the $1^{\text {st }}$ century, was of its double present size, that is dimensioned app. $1000 \times 430$ meters, covering the area of app. 43 ha, and housing not only one, but two legions: IIII Flavia felix and VII Claudia pia fidelis. Such conclusion may be made according to some interesting facts: southern wall of the military camp connects to the southern rampart of the town of Viminacium. The photos very clearly show that ramparts are continuous. It is very important, in the light of the fact that the northern town rampart and the town structure in that zone exclude (of course, if it had existed 
there) the castrum northern rampart. The main question to be asked is how the southern town rampart is so clearly detected and connected to the castrum sothern rampart? The self-imposing answer is that it was functional. Now, what was its function? Careful analysis of aerophotos of that spot show a structure placed immediately next to the southern town rampart. It is of rectangular basis with round sides. Our guess is that there was, since the early period of town formation, a hippodrome, most probably since the second half of the 1st century (Structure 12, Fig. 5-6). If the assumption that the two mentioned legions have been placed in the camp is true, they could have been together only till the Domitian's edict from 86 , by which stationing of two legions in one camp was forbidden. After 86, only the VII Claudia fia fidelis legion remained in the camp, and it had no need for such a large area, so the camp (castrum) was reduced to dimensions of $430 \times 377$ meters. A part of the southern rampart of the camp was used as a side for the newly made hippodrome.

It may also explain round structures vertical to the town rampart, which indicate communication surely existing there, but also most likely an imperial palace, having in mind great significance Viminacium had for the Roman Empire.

To the east, extending the eastern gate of the military camp (Fig. 5-6), more structures are detected which may be grouped into two groups. One is connected to communications leading from the neighbouring Lederate military camp (Structure 13, Fig. 5-6), another regards the military supply of the town of Viminacium and the camp (Structures 14, 15, 16, 17, Fig 5-6 as well as photos of aquaduct- georadar and archaeological photos Fig. 2).

The structure marked with No. 18 has a tumul form, but no clear function. Structures under No.19, 20 and 21 also need archaeological excavation in order to be defined, and interpreted later on (Fig. 5-6).

Another structure identified by georadar should be mentioned, which was eventually archaelogically studied. It is a late roman villa from the $4^{\text {th }}$ century (Fig. 3, 5-6).

Total result of the stereoscopic analysis of the archaeological site of Viminaciuma, the classical town and the military camp, is extremely significant. Twenty one structures of great importance for archaeologists have been detected. Stereoscopic analysis of the Viminacium site will be completed in the following period with infrared shots. Without doubt, cleared satelite images will give precious information on this exceptional site.

\section{ANALYSE OF DIGITAL IMAGES AND GIS}

Computer made revolution in application of remote sensing. Digital images are more manipulative than hardcopies. Software can enchance images and amplify diferencies to bring out buildings and structures. It is posible by changing contrasts, colours, brightness amd other visual effects.

When comparing to other presented images in this article figure No. 7 gives diffrenet example. Remote sensing is best used for large scale detection - city wals, aqueducts and macrostructures. On the other hand it can be also used for detecting single buildings or complexes. Complex presented on figure 7 was detected by changing contrasts of the digital image. You can see original segment, enchanced contrasts and one of posible interpretations of discovered building.

All aerial photos of Viminacium are digitised in high resolution. Topographic maps are also digitalised. In that way a solid base for application of remote sensing and GIS (Geographic Information System) is prepared. A complex data base is organized. Georeferencing of digital images is posible and applied. Every point is precisly defined in 2D.

Discovered buildings are easy to locate in the field using high precision Trimble 5800 GPS.

GIS software allows comparative analayze of several aerial, satelite photos and maps grouped in layers. Using transparencies of diferent layers is highly recomendable. In this way you can see features that were visible only in specific years or periods of a year.

Application of remote sensing and GIS in archaeology is of a great importance. Viminacium is the best example of this use in Serbia. Results achieved are highly valuable. In future this should be this should be the first step in any major archaeological project. 


\section{BIBLIOGRAPHY}

[1] Renfrew, C - Bahn, P., 2000: Archaeology, Theories Methods and Practice, $3^{\text {rd }}$ ed., London 2000, 71-116.

[2] Pritchard, J. B., (ed), 1987: The Times Atlas of the Bible, London 1987.

[3] Daniel, G. E., (ed.) 1981: Towards a History of Archaeology, London 1981.

[4] Gumerman G. J. \& Neely, 1972: An archaeological survey of the Tehuacan Valley, Mexico: A test of color infrared photography, American Antiquity 37, 520-527.

[5] Wilson, D. R., 1975: Aerial Reconnaissance for Archaeology. Concil for British Arch. Res. Rep., 12, London, 1975.

[6] Bradford, I. S. P., 1957: Ancient Landscapes: Studies in Field Archaeology, London 1957.

[7] Wilson, D. R., 1982: Air Photo Interpretation for Archaeologists, Batsford, London. 1982.

[8] Gumerman, G. J., and T. R. Lyons, 1971. Archeological Methodology and Remote Sensing. Science 172:126-32.

[9] Limp, W. F. 1989. The Use of Multispectral Digital Imagery in Archeological Investigations. Fayetteville: Arkansas Archeological Survey.

[10] Schaber, G. G., and G. J. Gumerman, 1989. Infrafed Scanning Imagery: An Archeological Application. Science 164:712-13. 


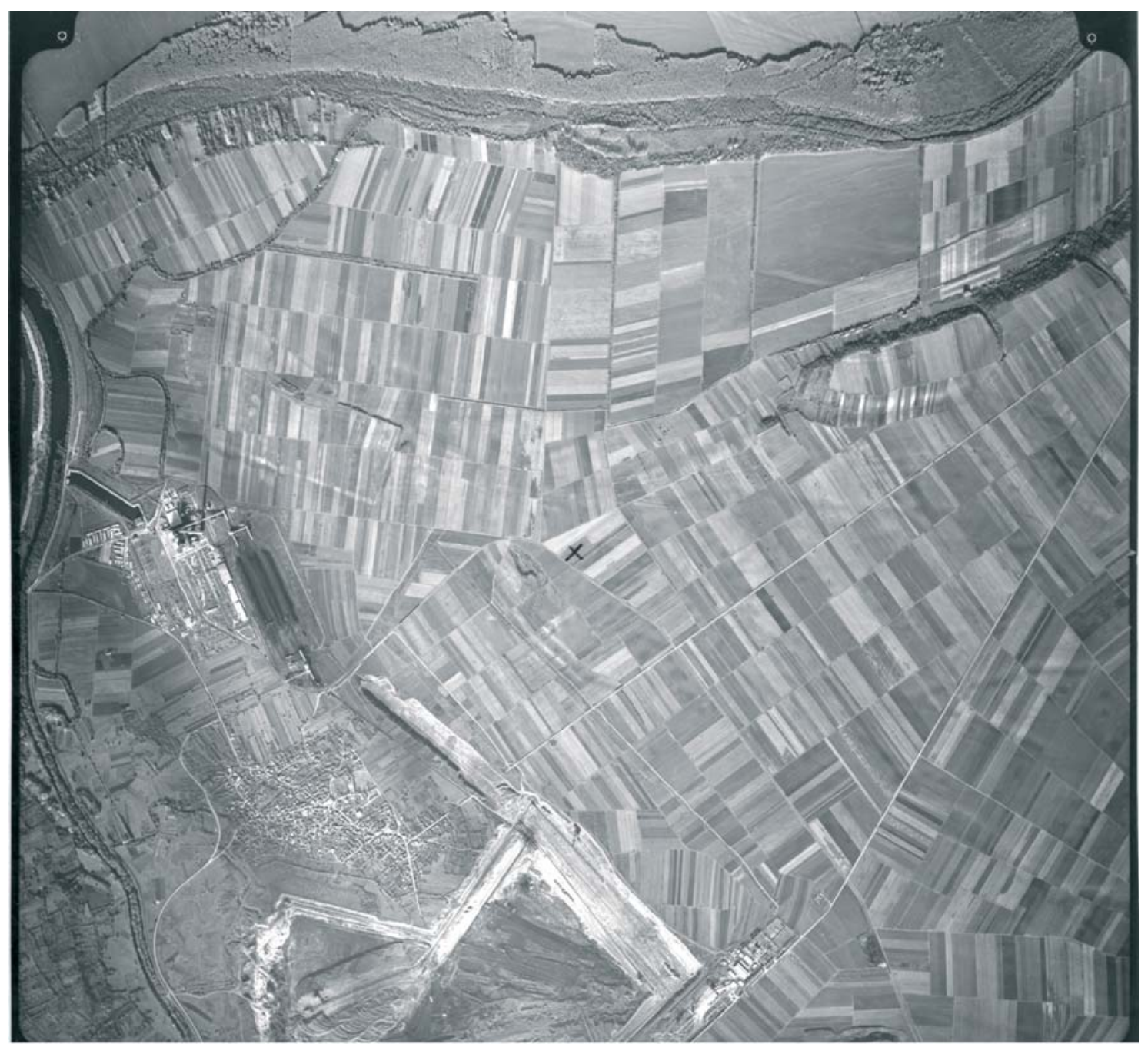

Slika 4. - Viminacium: Aerosnimak rimskog grada i vojnog logora sa neposrednom okolinom iz 1996. godine

Figure 3. Viminacium: Aerial photo of roman city and military camp with vicinity taken in 1996 


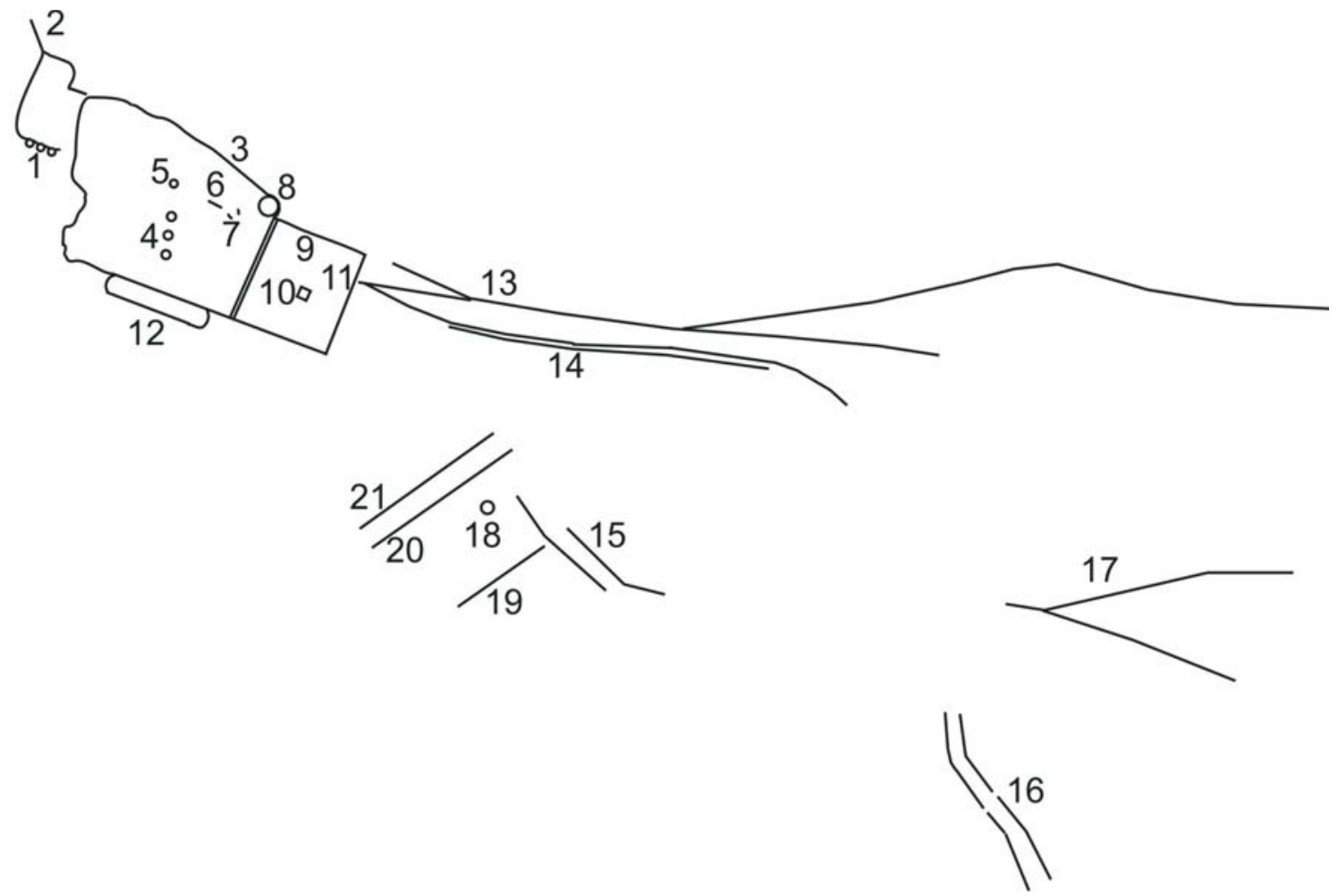

Slika 5. - Viminacium: 1 Kružne kule (Round towers); 2. Kapija (Port);

3. Bedemi (Walls); 4, 5. Hramovi (Temples?), 6. Ulica (Street);

7. Javna kupatila - Thermae (Bath); 8. Amfiteatar (Amphitheater);

9. Legijski logor (Legionary camp);

10. Vojna komanda - Praetorium i Principium (Headquarters);

11. Istočna kapija (Eastern Gate); 12. Hipodrom (Hippodrome);

13. Putevi (Road); 14, 15, 16, 17. Akvedukt (Aquaeduct); 18. Tumul, 19.20.21. Nepoznato (Unknown) 


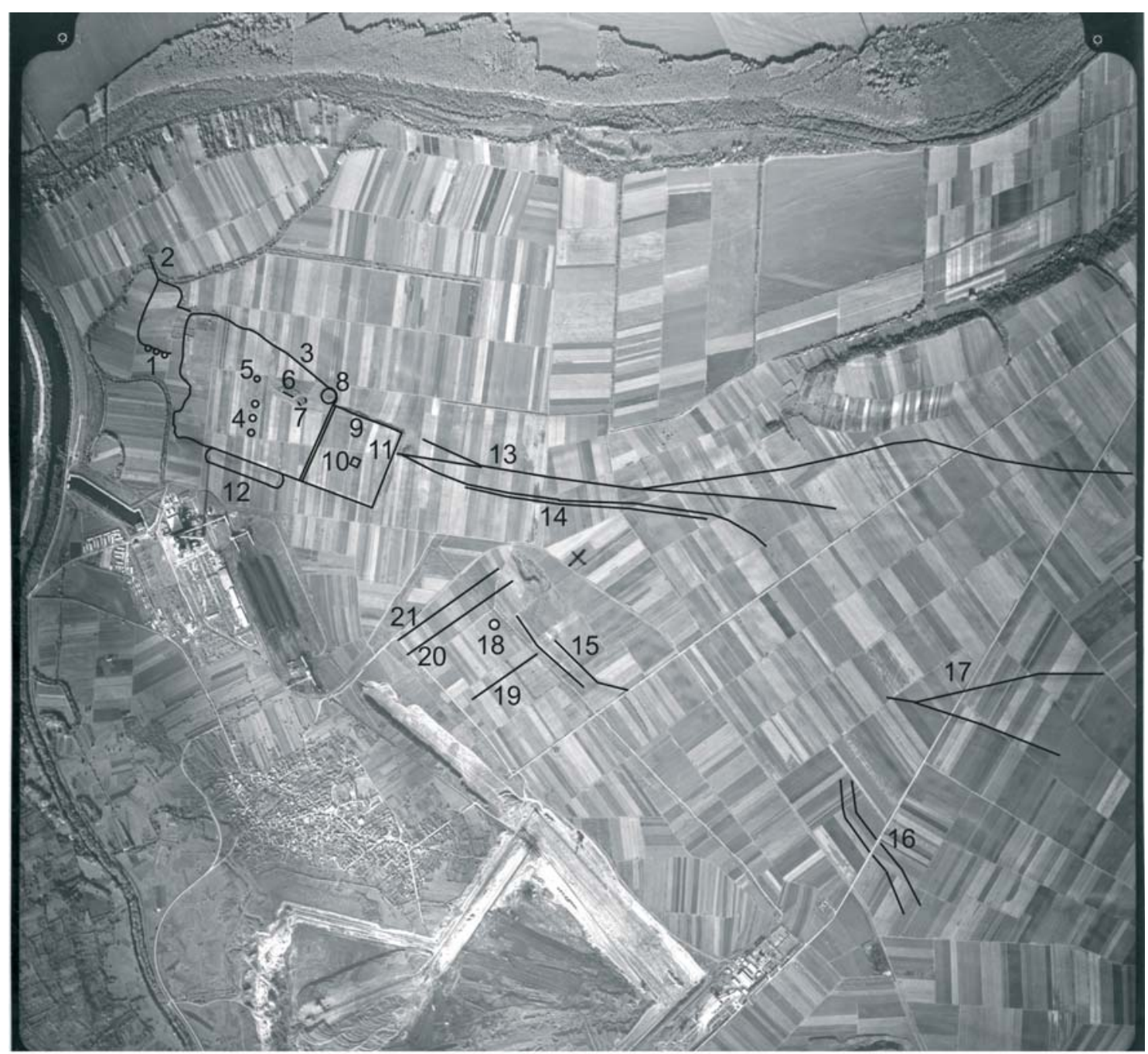

Slika 6. - Viminacium: Viminacium (oleata): 1 Kružne kule (Round towers);

2. Kapija (Port); 3. Bedemi (Walls); 4, 5. Hramovi (Temples?), 6. Ulica (Street);

7. Javna kupatila - Thermae (Bath); 8. Amfiteatar (Amphitheater);

9. Legijski logor (Legionary camp);

10. Vojna komanda - Praetorium i Principium (Headquarters);

11. Istočna kapija (Eastern Gate); 12. Hipodrom (Hippodrome);

13. Putevi (Road); 14, 15, 16, 17. Akvedukt (Aquaeduct); 18. Tumul, 19.20.21. Nepoznato (Unknown) 

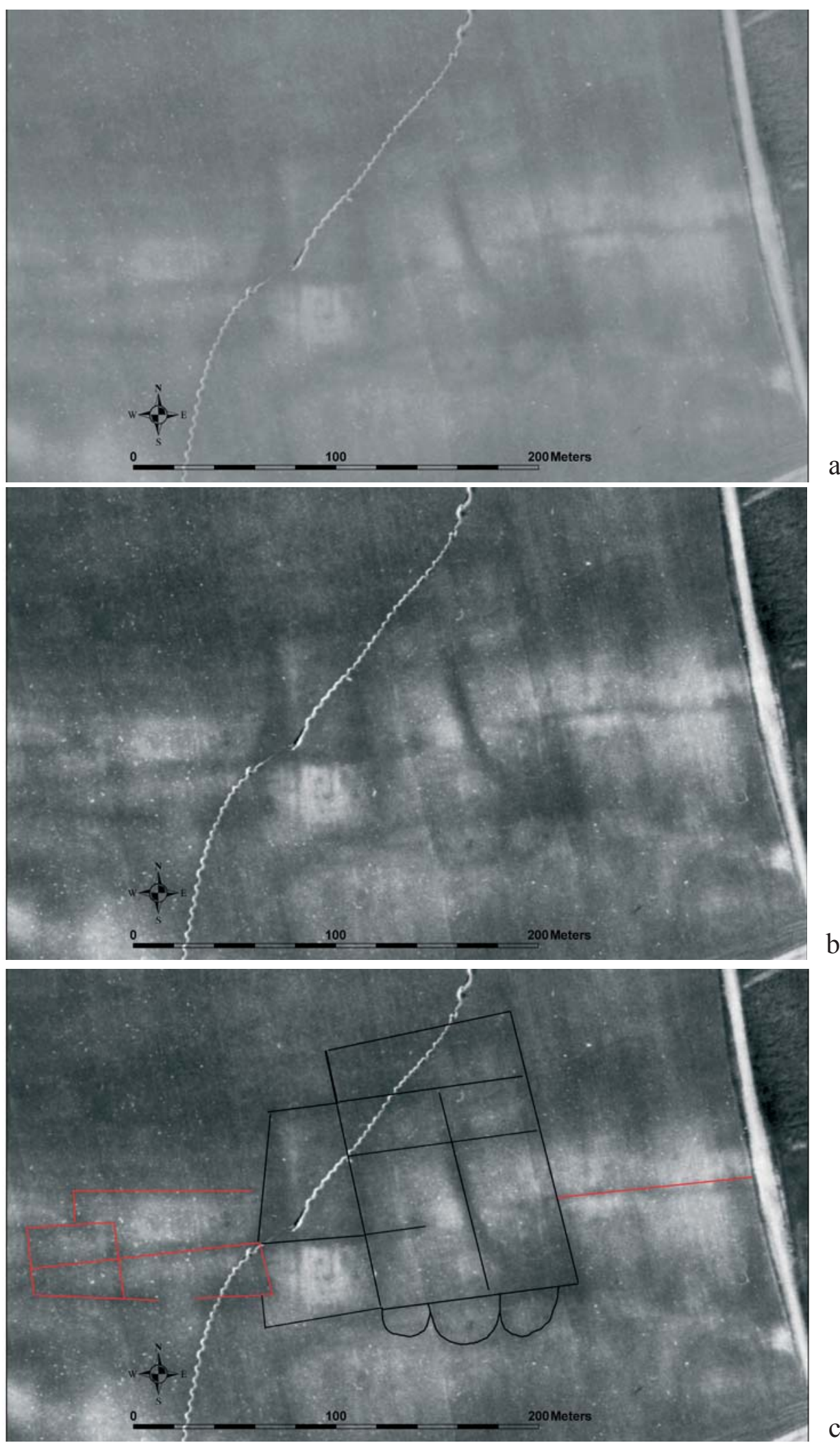

Slika 7. - Detalj objekta istočno od castruma - originalni snimak (a), pojačani kontrasti na snimku (b), jedna od mogućih interpretacija uočenog objekta (c)

Figure 6. - Detail of a complex east of military camp - original aerial photo (b), altered contrasts on the same photo (b), one of the posible interpretations (c) 